\title{
Africa's HIV transmission laws based on questionable science
}

Faced with an AIDS epidemic that kills millions every year, countries in sub-Saharan Africa are contemplating a new prevention strategy: criminal charges.

Uganda, touted as the rare success story in the region, is the latest nation to propose a law that would criminalize knowingly transmitting HIV to another person, the country's health minister announced in June. Since 2001, Zimbabwe, Lesotho and Swaziland have also adopted similar laws.

Few say the laws do what they're intended to: reduce the spread of HIV. "They make lawmakers feel good, but they have very limited positive benefits for the public," says Jonathan Berger, head of policy and research at the

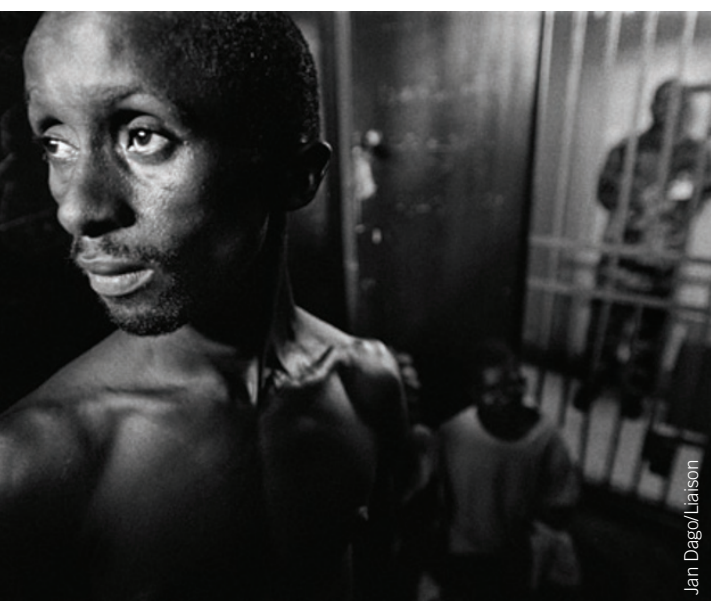

Crime and punishment: Genetic analysis cannot prove that one person infected another with HIV.
Johannesburg-based AIDS Law Project.

Apart from stigmatizing the disease more than it already is, critics warn, the laws ignore the fact that these countries may not have the resources to perform the careful genetic analysis required to distinguish the innocent from the guilty.

Phylogenetic analysis helps pinpoint how closely related two isolates of HIV are. In a criminal case, a virologist would obtain genetic sequences of the virus from both parties involved and compare them to sequences in a database, such as the US National Institutes of Health's GenBank, or from other infected individuals in the community.

If the viruses appear more closely related to each other than they are to samples taken from the larger population, it increases the likelihood that one person infected the other.

The procedure has its limitations, however. "It doesn't say anything about the direction of movement. It doesn't say anything about timing. It doesn't even really say that the transmission took place between the two people," says Yusef Azad, director of policy and campaigns at the National AIDS Trust, a UK-based advocacy group. "They both could have been infected by a third party."

Still, phylogenetics can exonerate the innocent. If the two HIV samples aren't closely related, it's unlikely one person could have infected the other. "The greatest power of it is exculpatory," says Gerald Learn, a microbiologist at the University of Washington. "If I was a defense lawyer, I would insist on it."

But the procedure is complicated and costly. "Scientists who are not trained in this field couldn't just read published reports and try to do this on their own without having the proper tools," says Michael Metzker, assistant professor of molecular genetics at the Baylor College of Medicine in Houston.

Genetic analysis of each HIV sample can require more than 100 sequences, with a price tag between $\$ 1$ and $\$ 5$ per sequence-no small sum in a developing country.

A few labs in Uganda are equipped to do the analyses, says Maria Wawer, a professor of population, family and reproductive health at Johns Hopkins University who conducts research in Uganda. "But it is likely to remain too expensive for the foreseeable future," she says.

Courts in these countries may instead rely on circumstantial evidence, raising the risk of wrongful convictions.

"In the absence of really clear scientific evidence as to who infected whom," says Azad, "there will too often be an assumption that those categorized as undesirable by society are guilty of infecting other people."

In 2002, UNAIDS argued against laws that penalize HIV transmission, recommending instead that responsible individuals be prosecuted using standard criminal laws, notes Azad. "Any legislation which singles out HIV for this kind of criminal sanction is breaching international human rights guidelines."

Cassandra Willyard, New York

\section{UK set to reverse stance on research with chimeras}

UK scientists who aim to use chimerashybrid embryos containing both human and animal material-for their research are awaiting a decision that would legalize their experiments.

In December 2006, the UK government proposed a total ban on the creation of any hybrid embryo containing human material, even for research purposes, but relented after an outcry from research organizations and political watchdogs.

The new draft regulations, published in May, set out a list of techniques that would be allowed, including the creation of 'cybrid' embryos - which comprise human DNA implanted into an empty animal egg - and human embryos that express certain animal genes or contain animal cells. 'True' chimeras, in which human eggs are fertilized by animal sperm or vice versa, will still be banned.

The draft regulations are expected to be signed into law in September at the earliest. After that, the two research groups that

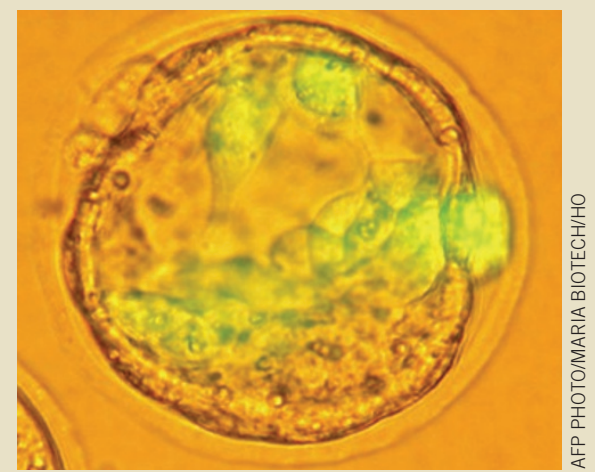

Back on track: Creation of chimeras is expected to be legalized in the UK in September. have applied to create cybrid embryos as a source of 'human' stem cells look set to have their requests granted.

But the holdup "has cost us a good solid year" of research time, says Stephen Minger, director of the Stem Cell Biology Laboratory at King's College London, one of the two institutions that has submitted applications.

Critics of the draft bill argue that the rules are too prescriptive, rather than being truly permissive.

"The government gives no good reason why some mixtures of human and animal genes in early laboratory embryos should be allowed and why others should be banned," says Evan Harris, a member of the Parliamentary Select Committee on Science and Technology, which produced 